\title{
Primary research \\ Expression of LRP and MDR1 in locally advanced breast cancer predicts axillary node invasion at the time of rescue mastectomy after induction chemotherapy
}

\author{
José Schneider+, Severino Gonzalez-Roces ${ }^{\ddagger}$, Marina Pollán§, Raul Lucas*, Armando Tejerina*, \\ Miguel Martin*ף and Alfonso Alba
}

${ }^{*}$ Centro de Patologia de la Mama, Madrid, Spain

+Universidad del Pais Vasco, Bilbao, Spain

*Instituto de Estudios Celulares y Moleculares, Lugo, Spain

SInstituto Nacional de Epidemiología, Madrid, Spain

IUniversidad Complutense, Madrid, Spain

Correspondence: J Schneider, Fundación Tejerina - Centro de Patologia de la Mama, Calle Jose Abascal 40, E-28003 Madrid, Spain. Tel: +34 91 3994280; fax: +34 91 4460253; e-mail: schneider@teleline.es

Received: 30 August 2000

Revisions requested: 9 November 2000

Revisions received: 8 January 2001

Accepted: 19 January 2001

Published: 1 February 2001
Breast Cancer Res 2001, 3:183-191

(C) 2001 Schneider et al, licensee BioMed Central Ltd (Print ISSN 1465-5411; Online ISSN 1465-542X)

\begin{abstract}
Background: Axillary node status after induction chemotherapy for locally advanced breast cancer has been shown on multivariate analysis to be an independent predictor of relapse. However, it has been postulated that responders to induction chemotherapy with a clinically negative axilla could be spared the burden of lymphadenectomy, because most of them will not show histological nodal invasion. Pglycoprotein expression in the rescue mastectomy specimen has finally been identified as a significant predictor of patient survival.

Materials and methods: We studied the expression of the genes encoding multidrug resistance associated protein (MDR1) and lung cancer associated resistance protein (LRP) in formalin-fixed, paraffin-embedded tumor samples from 52 patients treated for locally advanced breast cancer by means of induction chemotherapy followed by rescue mastectomy. P-glycoprotein expression was assessed by means of immunohistochemistry before treatment in 23 cases, and by means of reversetranscriptase-mediated polymerase chain reaction (RT-PCR) after treatment in 46 (6 failed). LRP expression was detected by means of immunohistochemistry, with the LRP-56 monoclonal antibody, in 31 cases before treatment. Immunohistochemistry for detecting the expression of c-erb-B2, p53, Ki67, estrogen receptor and progesterone receptor are routinely performed in our laboratory in every case, and the results obtained were included in the study. All patients had received between two and six cycles of standard 5-fluorouracil, doxorubicin and cyclophosphamide (FAC) chemotherapy, with two exceptions [one patient received four cycles of a docetaxel-adriamycin combination, and the other four cycles of standard cyclophosphamide-methotrexate-5-fluorouracil (CMF) polychemotherapy]. Response was assessed in accordance with the Response Evaluation Criteria In Solid Tumors (RECIST). By these, 2 patients achieved a complete clinical response, 37 a partial response, and the remaining 13 showed stable disease. This makes a total clinical response rate of $75.0 \%$. None achieved a complete pathological response.

Results: MDR1 mRNA expression detected by RT-PCR was associated with the presence of invaded axillary nodes at surgery in 18/22 cases (81.8\%), compared with $13 / 24$ (54.2\%) in the group with undetectable MDR1 expression. This difference was statistically significant $(P<0.05)$. LRP expression in more than $20 \%$ of tumor cells before any treatment was associated with axillary nodal metastasis after chemotherapy and rescue mastectomy in 17/23 cases, compared with $3 / 8$ in nonexpressors.
\end{abstract}

$\mathrm{CMF}=$ cyclophosphamide-methotrexate-5-fluorouracil; RT-PCR $=$ reverse-transcriptase-mediated polymerase chain reaction. 
Again, this difference was highly significant $(P<0.01)$. LRP expression before treatment and MDR1 mRNA expression after treatment were significantly interrelated $(P<0.001)$, which might reflect the presence of chemoresistant clones liable to metastasize to the regional nodes. Persistence of previously detected MDR1-positivity after treatment (7/9 compared with 0/2 cases) was significantly associated with axillary node metastasis $(P<0.05)$. Finally, in a logistic regression multivariate model, histology other than ductal, a Ki67 labeling index of at least 20\% and the combination of LRP and MDR1 positivity emerged as independent predictors of axillary node invasion at the time of rescue mastectomy.

Conclusion: The expression of different genes involved in resistance to chemotherapy, both before and after treatment with neoadjuvant, is associated with the presence of axillary node invasion at rescue surgery in locally advanced breast cancer. This might reflect the presence of intrinsically resistant clones before any form of therapy, which persist after it, and could be helpful both for prognosis and for the choice of individual treatment.

Keywords: axillary nodes, chemotherapy, LRP, multidrug resistant, neoadjuvant

\section{Introduction}

Induction chemotherapy (or induction hormone therapy), followed by rescue mastectomy, with or without axillary dissection, is the most widely accepted standard of treatment for primarily inoperable breast cancer [1]. During the past two or three decades, this approach has been also employed increasingly for the downstaging of 'locally advanced breast cancer', a poorly defined term encompassing both primarily inoperable cancers and those that are strictly operable but present unfavorable prognostic features (such as large size, diffuse tumors and clinically involved axillary nodes). Consensus pending, it might be acceptable to include in this category any tumor from stage IIA and above from the International Federation of Gynecology and Obstetrics (FIGO) classification, with the still unresolved issue of whether inflammatory carcinomas belong to this group or are a completely different class of tumor [2]. The last step in this direction has been to submit patients with otherwise operable cancers to neoadjuvant chemotherapy, to increase the proportion of those amenable to breast conservation [3].

Axillary node status after induction chemotherapy for locally advanced breast cancer has been shown on multivariate analysis to be an independent predictor of relapse [4]. Complete pathological tumor response to induction chemotherapy has been shown to predict a tumor-free axilla on histology in 4 out of 22 instances (more than 90\%) [5]. As an extension of this, it has been postulated that responders to induction chemotherapy with a clinically negative axilla could be spared the burden of lymphadenectomy, because most of them will not show histological nodal invasion [3]. It would be interesting to identify mechanisms involved in the resistance to induction chemotherapy, because, arguably, it is from resistant clones that the shedding of tumor cells giving rise to local and distant metastasis can take place. An argument in favor of this hypothesis is the fact that $P$ glycoprotein expression in the rescue mastectomy specimen has been identified as a significant predictor of patient survival [6]. Because cancer-related death in breast cancer patients is ultimately caused by distant metastasis in most cases, it seems [6] that P-glycoprotein expression could indicate the presence of multidrugresistant clones, from which tumor recurrence and dissemination might arise.

However, expression of the gene encoding multidrug resistance associated protein (MDR1) is not the sole factor responsible for multidrug resistance, either in breast cancer or in any other tumor. If anything is clear at present about multidrug resistance, it is the fact that its possible causes are manifold and increasing with every new resistance-associated gene studied [7]. Therefore, the difficulty instead lies in which of the genes to investigate, and for which reasons, because the potential candidates are many. We have centered the present investigation on P-glycoprotein and lung cancer associated resistance protein (LRP) because adriamycin (doxorubicin) is the main chemotherapeutic agent in most combinations used when treating breast cancer patients with neoadjuvant therapy. P-glycoprotein (MDR1)-associated resistance is the paradigm of adriamycin-mediated resistance, at least under experimental conditions. In contrast, LRP is known to have a role in the chemoresistance of several cancers, most notably lung cancer (from which it derives its name), but also leukemias and ovarian cancer [8-10]. However, it has not been studied extensively until now in breast cancer, although Volm et al [11] have clearly shown that LRP is involved in resistance to adriamycin, and would therefore be a good candidate for research in association with this tumor for the above-mentioned reasons. 
We have studied the expression of MDR1 and LRP both before and after neoajuvant chemotherapy in the present series of patients. The results have been correlated with the response to treatment, the presence of invaded axillary nodes, and also with that of other conventional prognostic markers (hormone receptors, Ki67 labeling index, mutant p53 expression, and c-erb-B2 overexpression).

\section{Materials and methods}

For the present investigation we used tumor material from 52 patients operated on at our center after induction chemotherapy for locally advanced breast cancer. This consisted of three to six cycles of standard FAC (5-fluorouracyl, doxorubicin and cyclophosphamide, 500, 50 and $500 \mathrm{mg} / \mathrm{m}^{2}$, respectively, given on day 1 every 21 days) in 50 cases, the remaining two receiving four cycles of docetaxel-doxorubicin $\left(70 \mathrm{mg} / \mathrm{m}^{2}\right.$ and $100 \mathrm{mg} / \mathrm{m}^{2}$ on day 1 every 21 days) and four cycles of standard cyclophosphamide-methotrexate-5-fluorouracil (CMF), respectively. Four courses of chemotherapy were initially planned for every patient. Most of them completed this schedule (41/52). However, one patient received only two courses (owing to intolerance, accompanied by an excellent tumor response) and six patients were given three courses for similar reasons; at the other extreme, one and three patients needed five and six cycles of chemotherapy, respectively, to make them amenable to rescue surgery,

Response to treatment was evaluated in accordance with the newly recommended Response Evaluation Criteria In Solid Tumors (RECIST) [12]. By these criteria, after the completion of treatment, two patients showed a complete clinical response, 37 a partial response and 13 stable disease, yielding a total response rate of $75.0 \%$. For the assessment of tumor size we took the combined value of radiological and ultrasonographic measurements whenever possible (which was not true of the four diffuse tumors of the series, occupying clinically the whole breast). As an example, we considered a response to be partial if the combined value of the diminution in maximal diameter measured by both methods exceeded $30 \%$. This resulted in tumor sizes that were almost always less than those obtained by palpation, but permitted a more objective monitoring of response, according to the RECIST recommendations, because real tumor shrinkage is evaluated in this way and is not confounded by the response to therapy of the peritumoral inflammatory reaction. Initial tumor size thus ranged between 2.0 and $10.0 \mathrm{~cm}$, seven of them being T4b tumors (with clinically evident skin ulceration or histological confirmation of dermal invasion), and one a small $(2.0 \mathrm{~cm}) \mathrm{T} 4 \mathrm{a}$ carcinoma, fixed to the chest wall. Finally, in four patients two or more distinct tumor masses were identified in the mammograms. Histologically, 45 were infiltrating ductal carcinomas, six were lobular carcinomas, and the remaining one was an anaplastic, unclassifiable carcinoma, probably of ductal origin.
All cases were diagnosed pretherapeutically by means of a core biopsy, at which time hormone receptors, c-erb-B2, mutant p53 expression and the Ki67 labeling index were routinely determined. The immunohistochemical technique and the antibodies used are the standard ones employed at our laboratory, identical to those described recently by us for a series of T1 breast cancers [13]. At rescue mastectomy, 35 patients showed axillary nodal invasion, the number of affected nodes ranging between 1 and 32 . Roughly one-third of these patients (12/35) had 10 or more metastatic nodes (Table 1).

\section{Immunohistochemistry}

For the detection of MDR1 and LRP expression, we used the same technique as that described in [13], which involves microwave heating of the slides in citrate buffer for antigen unmasking [heat-induced epitope retrieval (HIER)]. The antibodies used were c494 (which reportedly does not cross-react with MDR3 and recognizes an internal epitope of P-glycoprotein) $(10 \mu \mathrm{g} / \mathrm{ml})$ and LRP-56 $(0.5 \mu \mathrm{g} / \mathrm{ml})$. For the evaluation of the MDR and LRP results we employed the semiquantitative scale used previously by us $[14,15]$, which takes into account both the strength of the staining reaction and the proportion of reactive tumor cells. After application of the scale, tumors were considered positive for MDR1 when there was distinct membrane staining (besides the ubiquitous and difficult to interpret cytoplasmic staining, which was more or less present in all specimens) in more than $10 \%$ of the tumor cells, and for LRP when more than $20 \%$ of the tumor cells showed specific staining against a negative background.

Immunohistochemistry in the rescue mastectomy specimens immediately after chemotherapy was useless, owing to huge background staining (which was often more intense than the one found in tumor cells) and the nonspecific (but also extremely strong) staining of tumor areas that were identified in the corresponding hematoxylineosin slides as areas of post-chemotherapy necrosis. Therefore, because a given gene can be transcribed only by living cells, in this study we considered only the presence of mRNA as indicative of MDR1 expression by the tumor after recent chemotherapeutic treatment. The antibodies used and positivity cutoffs (more than 10\% positive tumor cells) for c-erb-B2, p53, estrogen receptor and progesterone receptor were the same as those described in [13] and routinely employed at our laboratory.

\section{Reverse-transcriptase-mediated polymerase chain reaction ( $R T-P C R)$}

Three or four $10 \mu \mathrm{m}$ paraffin sections, corresponding to about $10 \mathrm{mg}$ of tissue, were trimmed of excess paraffin and placed in $1.5 \mathrm{ml}$ Eppendorf tubes with $1 \mathrm{ml}$ of xylene, vortex-mixed and centrifuged for $5 \mathrm{~min}$ at room temperature. The pellet was resuspended in $200 \mu \mathrm{l}$ of PCR buffer (200 mM Tris- $\mathrm{HCl}, \mathrm{pH} 8.4,500 \mathrm{mM} \mathrm{KCl}, 20 \mathrm{mM} \mathrm{MgCl}$, 
Table 1

\begin{tabular}{|c|c|c|c|c|c|c|c|c|c|c|c|c|}
\hline Histology & Size ir & $\begin{array}{l}\text { Number of } \\
\text { invaded nodes }\end{array}$ & erb & p53 & Ki67 (\%) & ER & PR & $\begin{array}{c}\text { c494 } \\
\text { MDR1 }\end{array}$ & LRP & Chemotherapy & Response & $\begin{array}{c}\text { MDR1 } \\
\text { (RT-PCR) }\end{array}$ \\
\hline Lobular & 8.0 & 32 & 0 & 0 & 30 & 0 & 0 & & & FAC4 & SD & 0 \\
\hline Ductal & 7.0 & 31 & 1 & 1 & 60 & 0 & 0 & & & Ttere-ADM4 & PR & 1 \\
\hline Ductal & 6.0 & 21 & 1 & 1 & 30 & 1 & 1 & & 1 & FAC4 & PR & 1 \\
\hline Ductal & 3.5 (T4b) & 20 & 1 & 0 & 5 & 0 & 0 & 0 & 1 & FAC3 & PR & 1 \\
\hline Ductal & 6.0 & 20 & 0 & 0 & 35 & 0 & 0 & 1 & 1 & FAC4 & SD & 1 \\
\hline Lobular & 7.0 & 18 & 0 & 0 & 20 & 1 & 1 & & & FAC4 & PR & 0 \\
\hline Ductal & 3 (T4b) & 16 & 0 & 0 & 30 & 1 & 1 & 0 & 1 & FAC4 & PR & 1 \\
\hline Ductal & Diffuse & 15 & 0 & 0 & 20 & 0 & 0 & & & FAC4 & PR & 0 \\
\hline Lobular & Diffuse & 11 & 0 & 0 & 80 & 1 & 1 & 1 & 1 & FAC6 & PR & 1 \\
\hline Ductal & 2.2 (T4b) & 10 & 0 & 1 & 30 & 0 & 0 & 0 & 1 & FAC4 & PR & 0 \\
\hline Ductal & 7.0 & 10 & 0 & 0 & 35 & 1 & 0 & 1 & 1 & FAC4 & PR & 1 \\
\hline Ductal & 3 (T4b) & 10 & 1 & 1 & 20 & 1 & 1 & & & FAC4 & PR & Failed \\
\hline Ductal & 5.0 & 9 & 1 & 0 & 20 & 0 & 0 & & & FAC4 & SD & Failed \\
\hline Ductal & $2.2+1.3$ & 9 & 1 & 0 & 50 & 1 & 1 & 0 & 1 & FAC4 & PR & 1 \\
\hline Ductal & 4.0 (T4b) & 8 & 1 & 1 & & 1 & 1 & & & FAC4 & PR & 0 \\
\hline Lobular & 3.0 & 8 & 0 & 0 & 2 & 1 & 1 & & 0 & FAC4 & SD & 0 \\
\hline Ductal & Diffuse & 7 & 1 & 0 & 20 & 1 & 0 & & 1 & FAC4 & SD & 1 \\
\hline Ductal & 8.0 & 7 & 1 & 1 & 50 & 0 & 0 & 1 & 1 & FAC4 & CCR & 1 \\
\hline Ductal & 5.0 (T4b) & 5 & 0 & 0 & 5 & 0 & 0 & & & FAC3 & PR & 0 \\
\hline Ductal & Diffuse & 4 & 0 & 0 & 50 & 1 & 0 & & 1 & FAC4 & PR & 1 \\
\hline Ductal & 10.0 & 3 & 0 & 0 & 80 & 0 & 0 & 1 & & FAC3 & PR & Failed \\
\hline Ductal & 6.0 & 3 & 1 & 0 & 40 & 0 & 0 & & 1 & FAC4 & SD & 0 \\
\hline Ductal & 4.5 (T4b) & 2 & 0 & 0 & 30 & 1 & 1 & & & FAC6 & SD & 1 \\
\hline Ductal & 2.5 & 2 & 0 & 0 & no & 0 & 0 & & & FAC4 & PR & Failed \\
\hline Ductal & 10.0 & 2 & 0 & 1 & 60 & 0 & 0 & & & FAC4 & CCR & 1 \\
\hline Ductal & $4.5+2.0$ & 2 & 0 & 0 & 25 & 1 & 1 & 0 & 0 & CMF4 & PR & 0 \\
\hline Ductal & 5.0 & 2 & 1 & 1 & 40 & 1 & 0 & 0 & & FAC4 & PR & 0 \\
\hline Ductal & 3.5 & 2 & 0 & 0 & 15 & 1 & 1 & 0 & 1 & FAC4 & SD & 0 \\
\hline Ductal & 3.0 & 2 & 0 & 1 & 35 & 0 & 0 & & 1 & FAC4 & SD & 0 \\
\hline Ductal & 2.0 & 2 & 0 & 0 & 30 & 1 & 0 & & 1 & FAC4 & PR & 1 \\
\hline Ductal & $2.6+2.3$ & 1 & 0 & 0 & 40 & 1 & 1 & & & FAC3 & PR & 1 \\
\hline Ductal & 3.5 & 1 & 0 & 0 & 15 & 1 & 1 & 1 & 1 & FAC4 & PR & 1 \\
\hline Undiff. & 6.0 & 1 & 0 & 1 & 45 & 0 & 0 & & & FAC6 & SD & 1 \\
\hline Lobular & 6.0 & 1 & 0 & 0 & 10 & 1 & 1 & 0 & 0 & FAC4 & PR & 0 \\
\hline Ductal & 3.0 & 1 & 0 & 1 & 70 & 0 & 0 & 1 & 1 & $\mathrm{FAC2}$ & PR & 1 \\
\hline Ductal & $5+2$ & 0 & 1 & 1 & 20 & 0 & 1 & & & FAC3 & PR & Failed \\
\hline Ductal & 3.5 & 0 & 1 & 0 & 12 & 0 & 0 & 0 & 0 & FAC3 & PR & 0 \\
\hline Ductal & 10.0 & 0 & 0 & 1 & 15 & 0 & 0 & & & FAC5 & SD & 0 \\
\hline Ductal & 6.0 & 0 & 0 & 1 & 15 & 1 & 1 & & & FAC4 & PR & 1 \\
\hline Lobular & 5.0 & 0 & 0 & 0 & 10 & 1 & 1 & 1 & 0 & FAC4 & PR & 0 \\
\hline Ductal & 5.0 & 0 & 0 & 0 & 10 & 1 & 1 & & & FAC4 & PR & 0 \\
\hline Ductal & 4.0 & 0 & 0 & 0 & 10 & 0 & 0 & 0 & 0 & FAC4 & PR & 0 \\
\hline Ductal & 5.0 & 0 & 0 & 0 & 10 & 1 & 1 & 0 & 1 & FAC4 & PR & ND \\
\hline Ductal & 6.0 & 0 & 1 & 1 & 25 & 1 & 1 & & & FAC4 & PR & 1 \\
\hline Ductal & $2.0(\mathrm{~T} 4 \mathrm{a})$ & 0 & 1 & 1 & 30 & 1 & 1 & & & FAC4 & SD & 0 \\
\hline Ductal & 5.0 & 0 & 0 & 0 & 25 & 1 & 0 & 0 & 0 & FAC4 & PR & 0 \\
\hline Ductal & 5.0 & 0 & 0 & 0 & 15 & 1 & 1 & 0 & 0 & FAC4 & PR & 0 \\
\hline Ductal & 6.0 & 0 & 0 & 1 & 80 & 0 & 0 & 0 & 1 & FAC4 & PR & 1 \\
\hline Ductal & 3.6 & 0 & 0 & 0 & 10 & 1 & 1 & 1 & 1 & FAC4 & SD & 0 \\
\hline Ductal & 3.5 & 0 & 0 & 1 & 15 & 0 & 0 & & 1 & FAC4 & PR & 1 \\
\hline Ductal & 4.0 & 0 & 0 & 0 & 20 & 1 & 0 & & 1 & FAC4 & PR & 0 \\
\hline Ductal & 5.0 & 0 & 0 & 0 & 10 & 1 & 1 & & 1 & FAC4 & PR & 0 \\
\hline
\end{tabular}

Responses: 1, positive, 0, negative. Positivity levels: MDR1 (c494), only membrane staining in more than 10\% of tumor cells; LRP, more than 20\% reactive cells (for details, see the text). CCR, complete clinical response; PR, partial response; SD, stable disease; F, 5-fluorouracyl; A, doxorubicin (adriamycin); C, cyclophosphamide; M, methotrexate; undiff, undifferentiated; ND, not done; Ttere, taxotere. 
diethyl pyrocarbonate-treated water). Then, $10 \%$ chelating ion exchange resin (Chelex ${ }^{\circledR}$ 100; Bio-Rad) was added before incubation of the mixture at $65^{\circ} \mathrm{C}$ for $20 \mathrm{~min}$. The mixture was precipitated $(8000 \mathrm{~g}, 10 \mathrm{~min})$ and $100 \mu \mathrm{l}$ of the supernatant was used for total RNA extraction with Trizol $^{\circledR}$ (Gibco BRL) in accordance with the manufacturer's instructions: a first lysis step in Trizol [40-60\% phenol, 10-20\% guanidine thiocyanate, 5-10\% ammonium thiocyanate, water and glycerol), followed by a precipitation step at $14,000 \mathrm{~g}$ for $15 \mathrm{~min}$. Afterwards, the upper phase was transferred to a new tube, avoiding the interphase, and precipitated in an equal volume of propan2-ol, then pelleted, washed and dried.

Total RNA, resuspended in diethyl pyrocarbonate-treated water was treated with DNase. Two $\mu$ of $10 \times$ DNase buffer (500 mM Tris- $\mathrm{HCl}, \mathrm{pH} 8.0,20 \mathrm{mM} \mathrm{MgCl}_{2}$ ) were added, along with $1 \mu \mathrm{l}$ of RNase-free bovine pancreatic DNase I (40 U/ $\mu$; B Boehringer Mannheim, Germany). This mixture was incubated at room temperature for $30 \mathrm{~min}$ and stopped by the addition of 0.1 vol. of $20 \mathrm{mM}$ EDTA.

Efficient cDNA synthesis and MDR1 RT-PCR was achieved by using a one-step method (SuperScript One Step $^{\text {TM }}$ RT-PCR System; Gibco BRL). Total RNA, DNAfree $(3-10 \mu \mathrm{l})$, was added to a buffer containing each dNTP at $0.2 \mathrm{mM}$ as well as $1.2 \mathrm{mM} \mathrm{MgSO}_{4}, 1 \mu \mathrm{l}$ of SuperScript $^{\mathrm{TM}}$ II/RT/Taq mix (containing reverse transcriptase and Taq DNA polymerase) and $0.2 \mu \mathrm{M}$ of each specific $m d r 1$ primer (umdr1, 5'-CCA TCA TTG CAA TAG CAG G-3'; $d m d r 1$, 5'-GAG CAT ACA TAT GTT CAA ACT TC$3^{\prime}$ ) and $\beta$-globin or GADPH (commonly used primers as an internal amplification control). RT-PCR was performed in a total volume of $25 \mu \mathrm{l}$. After incubation at $50^{\circ} \mathrm{C}$ for 20 min, the three-step PCR was performed for 35 cycles in a Perkin-Elmer 9700 thermal cycler: $30 \mathrm{~s}$ denaturation at $94^{\circ} \mathrm{C}$, followed by annealing for $20 \mathrm{~s}$ at $52^{\circ} \mathrm{C}$ and finally extension for $30 \mathrm{~s}$ at $72^{\circ} \mathrm{C}$.

Loading buffer $(1 \mu \mathrm{l})$ was added to a mixture containing $5 \mu \mathrm{l}$ of both $m d r 1$ and control amplified product and run in a $3 \%(\mathrm{w} / \mathrm{v})$ agarose gel at a constant $70 \mathrm{~V}$ in Tris-borateEDTA buffer for $45 \mathrm{~min}$. The size of amplified bands was 168 base pairs (bp) for mdr1 and $130-400$ for GADPH and $\beta$-globin, depending on the primers used.

Because of the conserved nature of the GADPH and $\beta$-globin genes, the coamplification of MDR1 with it results in all cases in the presence of at least one visible band, corresponding to the positive internal control, together with a lower-weight control for mdr1 amplification (Fig. 1).

\section{Statistics}

For the analysis of the association of the different variables with each other, we used Fisher's exact test or Spearman's correlation test for nonparametric variables, where
Figure 1

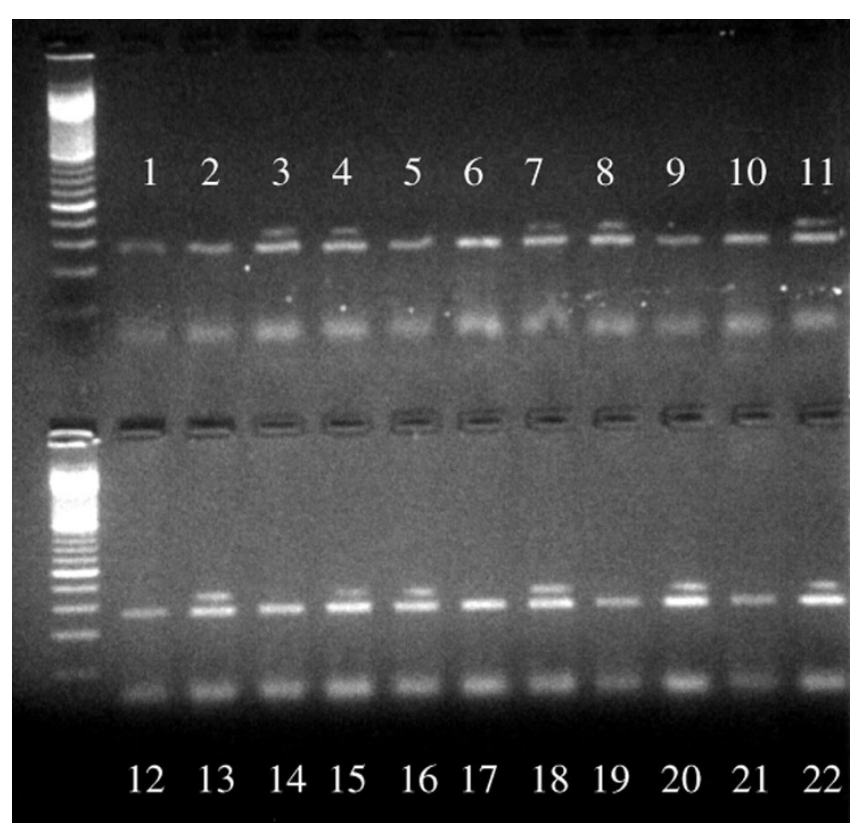

Ethidium-bromide-stained agarose gel after RT-PCR amplification of MDR1 mRNA. The MDR1-expressing tumors are demonstrated by the presence of a 168 base-pair band, above the $\beta$-globin positive control (lanes 3, 4, 7, 8, 11, 13, 15, 16, 18, 20 and 22).

applicable. This was performed by means of the GraphPad Prism statistical biomedical package (GraphPad Software, San Diego, California, USA). Furthermore, the strength of the association between each of the variables and the presence or absence of invaded axillary nodes (the endpoint of the study) was measured by means of unconditional logistic regression after calculation of its odds ratio, with the use of the STATA statistical package (Stata, College Station, Texas, USA). As a first step, a univariate analysis was performed (Table 2). Because MDR1 post-chemotherapy (RT-PCR) and LRP were interrelated (all MDR1-positive cases were also LRP-positive), both variables were subsequently combined into into a single one with three different categories: both negative, MDR1negative/LRP-positive and both positive. Information about this new variable was absent for 22 women. Given the relatively small sample size of the study, these missing values were treated as a separate category, which allowed us to include them in the multivariate analysis.

All variables that proved to be predictive in the univariate model were included in the multivariate analysis. However, once again taking into account the small sample number, we used less stringent significance criteria than usual, including in the final model some variables that failed to reach the common statistical boundary defined by a $P$ value of less than 0.05 . Furthermore, we tested whether or not the inclusion of any other predictor 
Table 2

\begin{tabular}{|c|c|c|c|c|c|c|}
\hline Factor & Variable & No. of women & Positive nodes (\%) & Odds ratio & $95 \% \mathrm{Cl}$ & $P$ \\
\hline \multirow[t]{2}{*}{ Histology } & Ductal & 45 & $29(64 \%)$ & 1.00 & & \\
\hline & Other & 7 & $6(86 \%)$ & 3.31 & $0.37-29.97$ & 0.287 \\
\hline \multirow[t]{2}{*}{ Tumor mass } & Single & 36 & $21(58 \%)$ & 1.00 & & \\
\hline & Other & 16 & $14(88 \%)$ & 5.00 & $0.99-25.34$ & 0.052 \\
\hline \multirow[t]{2}{*}{ Clinical response } & No & 13 & $(77 \%)$ & 1.00 & & \\
\hline & Yes & 39 & $25(64 \%)$ & 0.54 & $0.13-2.28$ & 0.398 \\
\hline \multirow[t]{2}{*}{ ER } & Negative & 22 & $16(73 \%)$ & 1.00 & & \\
\hline & Positive & 30 & $19(63 \%)$ & 0.65 & $0.20-2.14$ & 0.477 \\
\hline \multirow[t]{2}{*}{ PR } & Negative & 28 & $21(75 \%)$ & 1.00 & & \\
\hline & Positive & 24 & $14(58 \%)$ & 0.47 & $0.14-1.52$ & 0.205 \\
\hline \multirow[t]{2}{*}{ c-erb-B2 } & Negative & 37 & $24(64 \%)$ & 1.00 & & \\
\hline & Positive & 15 & $11(73 \%)$ & 1.49 & $0.37-5.62$ & 0.557 \\
\hline \multirow[t]{2}{*}{53} & Negative & 34 & $24(71 \%)$ & 1.00 & & \\
\hline & Positive & 18 & $11(61 \%)$ & 0.65 & $0.20-2.18$ & 0.489 \\
\hline \multirow[t]{2}{*}{ Ki67 } & $<20 \%$ & 17 & $6(35 \%)$ & 1.00 & & \\
\hline & $\geq 20 \%$ & 33 & $27(82 \%)$ & 8.25 & $2.18-31.23$ & 0.002 \\
\hline \multirow[t]{2}{*}{ MDR1 (IHC) } & Negative & 14 & $8(57 \%)$ & 1.00 & & \\
\hline & Positive & 9 & $7(78 \%)$ & 2.63 & $0.39-17.46$ & 0.318 \\
\hline \multirow[t]{2}{*}{ LRP } & Negative & 8 & $3(38 \%)$ & 1.00 & & \\
\hline & Positive & 23 & $17(74 \%)$ & 4.72 & $0.86-26.04$ & 0.075 \\
\hline \multirow[t]{2}{*}{ MDR1 (RT-PCR) } & Negative & 24 & $13(54 \%)$ & 1.00 & & \\
\hline & Positive & 22 & $18(82 \%)$ & 3.81 & $0.99-14.67$ & 0.052 \\
\hline \multirow{3}{*}{$\begin{array}{l}\text { MDR1 (RT-PCR) } \\
\text { and LRP combined }\end{array}$} & Both negative & 8 & $3(38 \%)$ & 1.00 & & \\
\hline & $\mathrm{LRP}^{+}$MDR1- & 7 & $4(57 \%)$ & 2.22 & $0.28-17.63$ & 0.450 \\
\hline & Both positive & 15 & $13(87 \%)$ & 10.83 & $1.37-85.43$ & 0.024 \\
\hline
\end{tabular}

$\mathrm{Cl}$, confidence interval; ER, estrogen receptor; PR, progesterone receptor; RT-PCR, reverse-transcriptase-mediated polymerase chain reaction.

improved the model. Finally, one powerful predictor for nodal invasion emerging from the univariate analysis was a histological variety different from ductal carcinoma (the most common one). In fact, out of seven of the patients carrying tumors with a different histology (six lobular and one undifferentiated carcinoma), six presented axillary invasion. To check the consistency of the odds ratios obtained from the final model, this was therefore fitted again, including only the homogeneous group of ductal infiltrating carcinomas (Table 3).

\section{Results}

MDR1 expression was measured by means of RT-PCR in rescue mastectomy specimens from patients previously subjected to induction chemotherapy for locally advanced breast cancer. MDR1-mRNA was successfully extracted from 51/52 tumor paraffin blocks, and was effectively retrotranscribed and amplified in $46 / 51$ instances. Additionally, MDR1 expression before chemotherapeutic treatment was assessed by means of immunohistochemistry in 23 cases. LRP expression before chemotherapy was studied accordingly in 31 cases.

The pretherapeutic expression of LRP in more than 20\% of tumor cells was significantly correlated with the subsequent presence of axillary nodal metastases (Spearman's test, $r=0.4725, P=0.0084$ ). In the preliminary univariate analysis giving rise to the final logistic regression model employed, LRP-positivity almost attained statistical significance for predicting nodal invasion (Table 2). Furthermore, 
Table 3

\begin{tabular}{|c|c|c|c|c|c|c|c|}
\hline \multirow[b]{2}{*}{ Factor } & \multirow[b]{2}{*}{ Variable } & \multicolumn{3}{|c|}{ Including all tumours } & \multicolumn{3}{|c|}{ Including only ductal carcinomas } \\
\hline & & Odds ratio & $95 \% \mathrm{Cl}$ & $P$ & Odds ratio & $95 \% \mathrm{Cl}$ & $P$ \\
\hline \multirow[t]{2}{*}{ Histology } & Ductal & 1.00 & & & & & \\
\hline & Other & 50.75 & $1.31-1968$ & 0.035 & & & \\
\hline \multirow[t]{2}{*}{ Tumor mass } & Single & 1.00 & & & 1.00 & & \\
\hline & Other & 4.64 & $0.66-32.60$ & 0.123 & 4.62 & $0.66-32.21$ & 0.122 \\
\hline \multirow[t]{2}{*}{ Ki67 } & $<20 \%$ & 1.00 & & & 1.00 & & \\
\hline & $\geq 20 \%$ & 7.68 & $1.43-41.11$ & 0.017 & 7.44 & $1.37-40.49$ & 0.020 \\
\hline \multirow[t]{4}{*}{ MDR1 and LRP } & Both negative & 1.00 & & & 1.00 & & \\
\hline & $\mathrm{LRP}^{+}$MDR1- & 9.16 & $0.36-232.1$ & 0.179 & 8.45 & $0.32-223.6$ & 0.202 \\
\hline & Both positive & 25.54 & $1.13-576.9$ & 0.042 & 23.60 & $1.00-558.6$ & 0.050 \\
\hline & Unknown & 4.78 & $0.29-79.26$ & 0.275 & 4.38 & $0.25-78.42$ & 0.315 \\
\hline
\end{tabular}

the immunohistochemical reaction is easy to judge because the antibody can be employed at relatively low concentrations for a monoclonal (see the Materials and methods section), and thus gives virtually no background staining (Fig. 2), which makes the detection of reactive tumor cells very easy. No association of LRP expression and the subsequent response to therapy could be discerned (although this observation is of little value, given the low sample number and the fact that most tumors showed some response).

MDR1 expression (membrane staining in more than 10\% of cells) measured by means of the c494 antibody (a close relative of the c219 antibody widely used by us in the past $[14,15]$, but unfortunately one that works only on freshly frozen material) was significantly correlated with subsequent nodal invasion (Spearman's test, $r=0.4763$, $P=0.022)$. However, significance was lost in the univariate model (Table 2). The logistic regression model is much more stringent, because it has to accommodate all data and because missing data are included in it as a distinct category, thus diluting the statistical power of some correlations, which nevertheless do exist if analyzed individually (as in this case).

The expression of MDR1 and that of LRP detected by immunohistochemistry before chemotherapy were correlated almost significantly $(P=0.12)$. Both were correlated with MDR1 mRNA expression after chemotherapy (LRP, $r=0.603, P=0.0004$; MDR1, $r=0.430, P=0.052)$.

An extremely interesting finding was that, out of nine immunohistochemically positive cases for MDR1 before chemotherapy, seven were still positive on RT-PCR after it. All seven of these patients had positive nodes. In con-
Figure 2

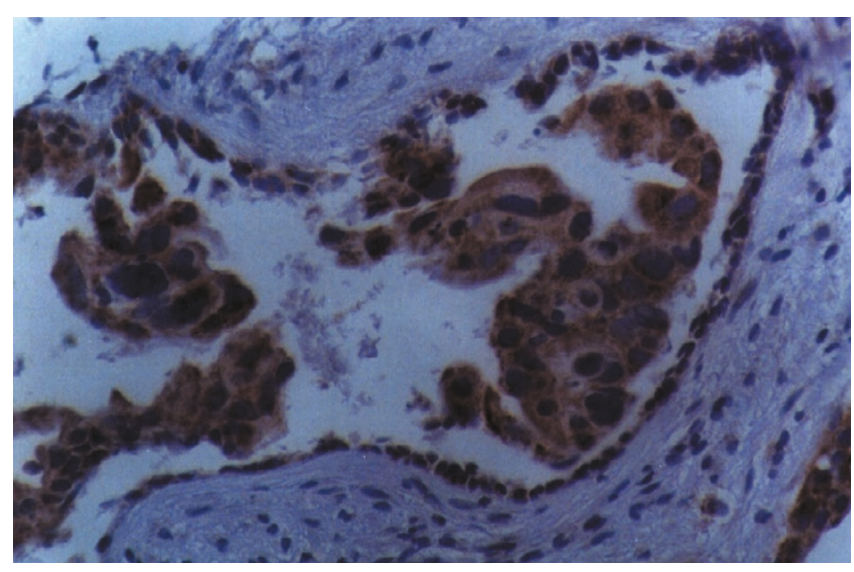

Strong reactivity with the LRP-56 monoclonal antibody of breast cancer tumor cells, as opposed to the inert stromal background. Streptavidin-biotin-peroxidase staining. Magnification $\times 400$.

trast, the other two patients, who converted to MDR1-negative after treatment, had negative nodes. Despite the extremely small number of patients involved, this yes/no difference was statistically significant (Fisher's exact test, $P=0.028$ ), and thus (with very much care) was not attributable to pure chance.

Finally, a Ki67 labeling index of at least 20\% positive tumor cells was also a significant predictor of axillary nodal invasion. In contrast, the finding of a single, mobile tumor mass confined to the breast gland, irrespective of size, was associated almost significantly with the absence of invaded nodes (Table 2). 
RNA of good enough quality for reverse transcription and amplification was retrievable from the paraffin blocks corresponding to $51 / 52$ patients, and was successfully reversetranscribed and amplified in 46 of them (90.2\%). Of these 46 patients, 22 showed the specific band corresponding to the MDR1 mRNA (Fig. 1) and were therefore classified as expressors of the gene. No attempts at further subclassification of the expression level by band densitometry were undertaken, although from Fig. 1 it is obvious that there are indeed differences, even if an internal balance is performed by comparison with the internal $\beta$-globin control. MDR1 expression in the rescue mastectomies demonstrated by this method was significantly correlated with nodal invasion (Spearman's test, $r=0.295, P=0.047$ ) when analyzed individually, and was associated with it almost significantly in the univariate model $(P=0.052)$. In fact, $18 / 22$ positive cases $(81.8 \%)$ showed nodal invasion, against only $13 / 24$ (54.2\%) negative ones.

In the final, multivariate model accommodating all potential predictors of axillary nodal invasion demonstrated by the univariate analysis, the following independent prognostic factors emerged: histology other than ductal, Ki67 at least $20 \%$, and a combination of LRP-positivity before chemotherapy with MDR1 positivity after treatment. Tumor presentation different from a solitary mobile mass (namely, diffuse T4a and T4b tumors in this study) attained almost independent predictive value (Table 3 ).

\section{Discussion}

The role of resistance-associated genes in the development of resistance to chemotherapy in humans is still controversial. Breast cancer is no exception, and the MDR1 gene in particular has been extensively studied in connection with it, although no definitive conclusion has been reached. Trock et al [16] addressed the possible significance of the MDR1 gene in breast cancer through a large meta-analysis, and cautiously stated in their conclusions that 'we found no evidence to support the assumption that MDR1/gp170 expression has no role in breast cancer' and, a little more daringly, that 'while the precise role of MDR1/gp170 in breast cancer remains to be established definitively, it seems likely that, in tumors where expression is detectable, this expression contributes to the multidrugresistant phenotype'. Our present findings seem only to corroborate this statement.

Furthermore, throughout their paper Trock et al stressed the difficulties imposed on their study by, for example, the various methodologies employed in the different reports that they considered, the heterogeneity of the patient populations studied, and the different reactivity patterns of the monoclonal antibodies used when performing immunohistochemistry. We can only agree with all these points raised, especially considering that 3 of the 31 studies included in their meta-analysis were by our own group
$[14,15,17]$, and we must humbly admit that their methodological criticisms largely apply to them (although also to most, if not all, other studies considered). This, however, speaks in favor of the plausible role of the MDR1 gene in the development of resistance to chemotherapy in breast cancer, which persisted throughout the meta-analysis, in spite of the many justified criticisms of the studies included in it.

In locally advanced breast cancer, where chemotherapy is the mainstay of treatment, a possible implication of the MDR1 gene in resistance and outcome has been found, directly or indirectly, in most studies since the initial one by Verrelle et al [18] until this present one. However, we have previously also found consistently that MDR1 expression is associated with the expression of the c-erb-B2 oncogene, both in breast cancer and in ovarian cancer $[15,17,19]$. Support for the notion that there is indeed some relationship between oncogenic activation including c-erb-B2 expression is provided by experimental evidence that the transfection of c-erb-B2 and c-Ha-ras to human breast epithelial cells that initially do not express the MDR1 gene confers on them the full MDR phenotype. So, MDR1 expression could indirectly represent just an increased malignancy of the tumors, and nodal invasion would simply reflect their increased aggressiveness, and not the existence of chemotherapy-resistant tumor cell clones.

However, the multivariate analysis of the present study shows that LRP and MDR1 expression is significantly associated with nodal metastasis independently of a high proliferation rate, which was another of the significant (and independent) predictors identified here. In addition, MDR1 and c-erb-B2 were not significantly coexpressed this time, which seems to contradict our previous reports; however, this might be attributable to several causes, among which are the different subsets of tumors studied in them (only T4b tumors in one, which are a minority in this study, and preselected, highly aggressive operable tumors in the other), the use of different tumor material, at least in the first study (frozen tumors), and the use of different antibodies (c219 and NCL-pGlyP). In the present study, the relationship of nodal invasion to the expression of MDR1 and LRP is therefore clearcut, and clearly outweighs an eventual association with c-erb-B2 expression or high proliferation. This might explain axillary node invasion purely as a function of tumor aggressiveness via oncogenic activation, with MDR1 and LRP expression being only a byproduct of it.

Our findings seem to reflect the existence of intrinsically resistant tumor cell clones before chemotherapeutic treatment, and their persistence after it, from which metastases, first local (nodal) and finally distant, might develop. In favor of this hypothesis stands the fact that MDR1 expression after chemotherapy for locally advanced breast 
cancer has been found to be associated with a worse final outcome of the patients [11], and if breast cancer patients die from their disease, they do so precisely because of distant metatstases. From our results, finally, it seems evident once more that resistance to chemotherapy is a multifactorial phenomenon, where not just one but many genes are involved.

\section{Acknowledgement}

This research was financed by grant FIS 99/0621 from Fondo de Investigación Sanitaria, Spain.

\section{References}

1. Kuerer HM, Newman LA, Fornage BD, Dhingra K, Hunt KK, Buzdar AU, Ames FC, Ross MI, Feig BW, Hortobagyi GN, Singletary SE: Role of axillary lymph node dissection after tumor downstaging with induction chemotherapy for locally advanced breast cancer. Ann Surg Oncol 1998, 5:673-680.

2. Singletary SE: Locally advanced breast cancer. In Breast Cancer. Atlas of Clinical Oncology. Edited by Winchester DJ, Winchester DP. London: B.C. Decker Inc, 2000:153-170.

3. Lenert JT, Vlastos G, Mirza NQ, Winchester DJ, Binkley SM, Ames FC, Ross MI, Feig BW, Hunt KK, Strom E, Buzdar AU, Hortobagyi GN, Singletary SE: Primary tumor response to induction chemotherapy as a predictor of histological status of axillary nodes in operable breast cancer. Ann Surg Oncol 1999, 6: 762-767.

4. Botti C, Vici P, Lopez M, Scinto AF, Cognetti F, Cavaliere R: Prognostic value of lymph node metastases after neoadjuvant chemotherapy for large-sized operable carcinoma of the breast. J Am Coll Surg 1995, 181:202-208.

5. Kuerer HM, Newman LA, Buzdar AU, Dhingra K, Hunt KK, Buchholz TA, Binkley SM, Strom EA, Ames FC, Ross MI, Feig BW, McNeese MD, Hortobagyi GN, Singletary SE: Pathologic tumor response in the breast following neoadjuvant chemotherapy predicts axillary lymph node status. Cancer J Sci Am 1998, 4:230-236.

6. Chung HC, Rha SY, Kim JH, Roh JK, Min JS, Lee KS, Kim BS, Lee KB: P-glycoprotein: the intermediate end point of drug response to induction chemotherapy in locally advanced breast cancer. Breast Cancer Res Treat 1997, 42:65-72.

7. Volm M: Multidrug resistance and its reversal. Anticancer Res 1998, 18:2905-2917.

8. Izquierdo $M A$, van der Zee $A G$, Vermorken JB, van der Valk $P$ Belien JA, Giaccone G, Scheffer GL, Flens MJ, Pinedo HM, Kenemans P, Meijer CJLM, de Vries EGE, Scheper RJ: Drug-resistance-associated marker Lrp for prediction of response to chemotherapy and prognoses in advanced ovarian carcinoma. J Natl Cancer Inst 1995, 87:1230-1237.

9. Volm M, Stammler G, Zintl F, Koomagi R, Sauerbrey A: Expression of lung-resistance protein (LRP) in initial and relapsed childhood acute lymphoblastic leukemia. Anticancer Drugs 1997, 8:662-665.

10. Scheffer GL, Schroeijers AB, Izquierdo MA, Wiemer EA, Scheper $\mathrm{RJ}$ : Lung resistance-related protein/major vault protein and vaults in multidrug-resistant cancer. Curr Opin Oncol 2000, 12:550-556.

11. Volm M, Mattern J, Koomagi R: Expression of lung resistancerelated protein (LRP) in non-small cell lung carcinomas of smokers and non-smokers and its predictive value for doxorubicin resistance. Anticancer Drugs 1997, 8:931-936.

12. Therasse P, Arbuck SG, Eisenhauer EA, Wanders J, Kaplan RS, Rubinstein R, Verweij J, van Glabbeke M, van Oosterom AT, Christian MC, Gwyther SG: New guidelines to evaluate the response to treatment in solid tumors. I Natl Cancer Inst 2000, 92:205-216.

13. Schneider J, Pollán M, Ruibal A, Jiménez E, Lucas AR, Núñez MI, Sánchez J, Tejerina A: Histologic grade and CD44 are independent predictors of axillary node invasion in early (T1) breast cancer. Tumor Biol 1999, 20:319-330.

14. Schneider J, Bak M, Efferth T, Kaufmann M, Mattern J, Volm M: P glycoprotein expression in treated and untreated human breast cancer. Br J Cancer 1989, 60:815-818.
15. Schneider J, Rubio MP, Barbazan MJ, Rodriguez-Escudero FJ, Seizinger BS, Castresana JS: P-glycoprotein, HER-2/neu and mutant p53 expression in human gynecologic tumors. J Natl Cancer Inst 1994, 86:850-855.

16. Trock BJ, Leonessa F, Clarke R: Multidrug-resistance in breast cancer: a meta-analysis of MDR1/gp170 expression and its possible functional significance. J Natl Cancer Inst 1997, 89: 917-931.

17. Schneider J, Romero H: Correlation of P-glycoprotein overexpression and cellular prognostic factors in formalin-fixed, paraffin-embedded tumor samples from breast cancer patients. Anticancer Res 1995, 15:1117-1121.

18. Verrelle $P$, Meisonnier F, Fonck $Y$, Feillel V, Dionet $C$, Kwiatkowski $\mathrm{F}$, Plagne R, Chassagne J: Clinical relevance of immunohistochemical detection of multidrug resistance P-glycoprotein in breast carcinoma. J Natl Cancer Inst 1991, 83:111-116.

19. Schneider J, Centeno M, Jimenez E, Rodriguez-Escudero FJ Romero H: Correlation of MDR1 expression and oncogenic activation in human epithelial ovarian carcinoma. Anticancer Res 1997, 17:2147-2152. 